\title{
Ni-hemin metal-organic framework with highly efficient peroxidase catalytic activity: toward colorimetric cancer cell detection and targeted therapeutics
}

\author{
Negar Alizadeh ${ }^{1}$, Abdollah Salimi $^{1,2^{*}}$, Rahman Hallaj ${ }^{1}$, Fardin Fathi ${ }^{3}$ and Farzad Soleimani ${ }^{3}$
}

\begin{abstract}
Background: Given the great benefits of artificial enzymes, a simple approach is proposed via assembling of $\mathrm{Ni}^{2+}$ with hemin for synthesis of Ni-hemin metal-organic-frameworks (Ni-hemin MOFs) mimic enzyme. The formation of the Ni-hemin MOFs was verified by scanning electron microscopy, Transmission electron microscopy, X-ray powder diffraction, X-ray photoelectron spectroscopy, Fourier transform infrared spectroscopy, Energy-dispersive X-ray spectroscopy and UV-vis absorption spectroscopy. This novel nanocomposite exhibited surprising peroxidase like activity monitored by catalytic oxidation of a typical peroxidase substrate, 3,3,5,5'-tetramethylbenzidine, in the presence of $\mathrm{H}_{2} \mathrm{O}_{2}$. By using folic acid conjugated MOF nanocomposite as a recognition element, we develop a colorimetric assay for the direct detection of cancer cells.
\end{abstract}

Results: The proposed sensor presented high sensitivity and selectivity for the detection of human breast cancer cells (MCF-7) and Human Caucasian gastric adenocarcinoma. By measuring UV-vis absorbance response, a wide detection range from 50 to $10^{5}$ cells $/ \mathrm{mL}$ with a detection limit as low as 10 cells $/ \mathrm{mL}$ was reached for MCF-7 cells. We further discuss therapeutics efficiency of Ni-hemin MOFs in the presence of $\mathrm{H}_{2} \mathrm{O}_{2}$ and ascorbic acid. Peroxidase-mimic Ni-hemin MOFs as reactive oxygen species which could damage MCF-7 cancer cells, however for normal cells (human embryonic kidney HEK 293 cells) killing effect was negligible.

Conclusions: Based on these behaviors, the developed method offers a fast, easy and cheap assay for the interest in future diagnostic and treatment application.

Keywords: Ni-hemin MOF, Peroxidase activity, TMB, $\mathrm{H}_{2} \mathrm{O}_{2}, \mathrm{MCF}-7$ and Caucasian gastric adenocarcinoma cancer cells, Therapeutics efficiency

\section{Background}

Lately, artificial enzyme mimics are becoming a focus of great interest owing to the remarkable superiority that they offer over natural enzymes, such as highly stable and low-cost [1-3] nanozymes (nanomaterials with enzyme-like characteristics) generally exhibit superior catalytic activity and intrinsic ability to generate or scavenge reactive oxygen species due to their small size and

\footnotetext{
*Correspondence: absalimi@uok.ac.ir; absalimi@yahoo.com

1 Department of Chemistry, University of Kurdistan,

66177-15175 Sanandaj, Iran

Full list of author information is available at the end of the article
}

large surface area [4]. Since Gao et al. [5] reported that inert ferromagnetic nanoparticles with intrinsic horseradish peroxidase (HRP)-like activity, a numerous deal of excellent work about the enzyme mimics has been done, including $\mathrm{CeO}_{2}$ nanoparticle [6], $\mathrm{Co}_{3} \mathrm{O}_{4}$ Nanorods [7], $\mathrm{MnO}_{2}$ nanoparticles [8], $\mathrm{MoS}_{2}$ nanosheet [9], $\mathrm{CuO}$ nanoparticles [10], nitrogen-doped graphene quantum dots [11], Hematite-Silica Nanoparticles [12], and metal organic frameworks [13].

Metal-organic frameworks (MOFs) formed by selfassembly of metal ions and organic linkers, have recently emerged as new versatile materials. MOFs have received 
special interest owing to their attracting features including large specific surface area, large pore volume and high stability $[14,15]$. Because of unique characteristics of MOF, they have potential applications as functional materials in catalysis [16], separations [17], electronic [18], drug delivery [19], and sensing [20, 21].

Recently, some studies have been reported on MOF based biosensing. MIL-53(Fe) with intrinsic peroxidase-like catalytic activity can catalyze the oxidation of different peroxidase substrates such as $3,3^{\prime}, 5,5^{\prime}$-tetramethylbenzidine (TMB) and $o$-phenylenediamine (OPD) in the presence of $\mathrm{H}_{2} \mathrm{O}_{2}$ providing a new and simple colorimetric detection of hydrogen peroxide and ascorbic acid [22]. Metalloporphyrinic MOF is also a type of MOF which used as biomimetic catalysts for different reactions. Huang and co-workers grown Au nanoparticles (NPs) on 2D metalloporphyrinic-MOF nanosheets. This synthesized hybrid could act as the glucose oxidase (GOx) mimics and utilized to detect glucose [23].

Hemin, as one of the iron porphyrin derivatives, is the active center of heme-proteins, having abilities to mimic the active site of various enzymes. Due to molecular aggregation of hemine in aqueous solution to form catalytic inactive dimers and oxidative self-destruction in the oxidizing media, direct application of hemin is of significant challenge [24]. Therefore, the development of novel materials such as hemin supports to achieve biomimetic catalysts with enzyme-like activity is highly desired. So, various nanomaterials have been used as hemin support for improving its enzyme like activity. He et al. [25] have been introduced $\mathrm{Cu}$-hemin metal-organic frameworks as a kind of Metalloporphyrinic MOF and applied for electrochemical glucose biosensing. This ball-flower-like nanostructure with excellent catalytic activity toward the reduction of $\mathrm{O}_{2}$ was synthesized via $\mathrm{Cu}^{2+}$ coordinating with hemin, possess and used to load a large number of glucose oxidase (GOD) molecules. The pores of MOFs provide incorporating of GOD molecules into $\mathrm{Cu}$ hemin MOFs which effectively avoided the aggregation of enzyme on the surface of electrode. In addition, $\mathrm{Cu}$ hemin MOFs can be employ to colorimetric detection of $\mathrm{H}_{2} \mathrm{O}_{2}$ and glucose [26]. Nevertheless, there have been a few studies on usage of the intrinsic enzyme-like activities of MOF for biomedical applications such as cancer diagnostic [27].

Cancer is one of the killer sickness in the world and nowadays it has become a major public worry. Hence, it is highly required to develop rapid, sensitive and specific methods to identification and detection cancers [28-30]. Among various techniques of cancers diagnosis like cytologic testing [31], fluorescent imaging [32], X-ray imaging [33], low-cost and non-destructive methods are preferred for preclinical detection of cancer cells. Therefore, colorimetric methods have attracted significant attention for developing cytosensing platforms because they can reduce the cost and time required for analysis and usually performed with simple instrumentation [34, 35].

In this paper, we developed a facial approach to fabricate a new Ni-hemin MOF nanostructure via a one-step hydrothermal method for sensitive colorimetric detection of cancer cells. To the best of our knowledge, it is the first time that this type of the MOFs are used for the colorimetric detection of cancer cells. The resulting $\mathrm{Ni}$-hemin metal-organic framework exhibited intrinsic peroxidase-like activity and catalyze the oxidation of $3,3^{\prime}, 5,5$ - tetramethylbenzidine (TMB) by hydrogen peroxide. Therefore, the MOF nanocomposite conjugated with folic acid as cancer cell targeting ligand. The prepared immobilized nanocomposite was obtained to use as a powerful nanoprobe for sensitive and selective colorimetric detection of cancer cells, moreover for therapeutic cancer treatment through great peroxidase activity of the nanocomposite.

\section{Methods \\ Materials and instrumentation}

Nickel nitrate hexahydrate $\mathrm{Ni}\left(\mathrm{NO}_{3}\right)_{2} \cdot 6 \mathrm{H}_{2} \mathrm{O}$, cetrimonium bromide $(\mathrm{CTAB})$, phytic acid $\left(\mathrm{C}_{6} \mathrm{H}_{18} \mathrm{O}_{24} \mathrm{P}_{6}\right)$, hemin $\left(\mathrm{C}_{34} \mathrm{H}_{32} \mathrm{ClFeN}_{4} \mathrm{O}_{4}\right)$, were purchased from Sigma or Aldrich. $\mathrm{NH}_{3}, \mathrm{H}_{2} \mathrm{O}_{2}$ (30\%), 3,3',5,5'-tetramethylbenzidine (TMB), folic acid (FA), (3-Aminopropyl) triethoxysilane (APTES) and all other reagents of analytical grade were from Merck or Fluka. All chemicals and reagents were of analytical grade with the highest purity and directly used without further purification. Deionized water from a Milli-Q Plus system (Millipore) was used in all solutions and experiment. UV-visible absorption spectra and kinetic measurements were carried out on a SPECTROD 250-analytikjena spectrophotometer (Germany). Scanning electron microscopy (SEM) and Transmission electron microscopy (TEM) image were recorded on a MIRA3 TESCAN HV: $20.0 \mathrm{kV}$ from Czech Republic and Philips microscope (EM 280, Tokyo, Japan) respectively. X-ray diffraction (XRD) patterns were observed using a Bruker D8 Advance diffractometer equipped with a copper source and a general area detector diffraction system (GADDS). Netherlands). X-ray Photoelectron Spectroscopy (XPS) was recorded using Thermo Scientific ESCALAB 250 spectrometer with a mono X-ray source $\mathrm{Al} \mathrm{K}$ a excitation (1486.6 eV). Binding energy calibration was based on $\mathrm{C} 1 \mathrm{~s}$ at $284.6 \mathrm{eV}$.

\section{Synthesis of $\mathrm{Ni}$-hemin metal-organic framework}

Ni-hemin MOFs Nanocomposites were prepared as follows: Briefly, $0.28 \mathrm{~g} \mathrm{Ni}\left(\mathrm{NO}_{3}\right)_{2} \cdot 6 \mathrm{H}_{2} \mathrm{O}$ was dispersed in $20 \mathrm{~mL}$ of deionized water, then $0.055 \mathrm{~g}$ CTAB and 0.045 
phytic acid was added to solution and stirred at room temperature for $15 \mathrm{~min}$. Subsequently, $20 \mathrm{~mL}$ of $0.5 \mathrm{mM}$ hemin was mixed with the above solution, followed by adding $2 \mathrm{~mL}$ of ammonia solution. After continuous stirred for $10 \mathrm{~min}$, the product was then transferred to a 40-mL Teflon-lined stainless steel autoclave and kept in an oven at $150{ }^{\circ} \mathrm{C}$ for $8 \mathrm{~h}$. The autoclave was then taken out from the oven and left to cool to room temperature. The sediment was collected via centrifugation, washed thoroughly several times and dried at $60^{\circ} \mathrm{C}$ overnight.

\section{Preparation of folic acid/Ni-hemin MOF}

Firstly, $100 \mu \mathrm{L}$ APTES was added into $1 \mathrm{~mL}$ prepared Ni-hemin MOF $(1 \mathrm{mg} / \mathrm{mL})$ solution and stirred for $8 \mathrm{~h}$ at room temperature. After centrifugation to remove unbounded APTES, the sediment was resuspended in $1 \mathrm{~mL}$ PBS (pH 7.0). In the next step, $2 \mathrm{~mL}$ of folic acid $\left(0.5 \mathrm{mg} \mathrm{mL}^{-1}\right)$ was added to a solution containing EDC $\left(2 \mathrm{~mL}, 1 \mathrm{mg} \mathrm{mL}^{-1}\right)$ and NHS $\left(2 \mathrm{~mL}, 0.5 \mathrm{mg} \mathrm{mL}^{-1}\right)$ and stirred for $1 \mathrm{~h}$ at room temperature. The solution of folic acid was then mixed with APTES modified Ni-hemin MOF solution and stirred mechanically overnight. The obtained folic acid functionalized Ni-hemin MOF was subjected to centrifugalize at $3000 \mathrm{rpm}$ for $10 \mathrm{~min}$ and washed several times by ultrapure water. Finally, the precipitate was dispersed again in $2 \mathrm{~mL}$ PBS ( $\mathrm{pH} 7.0)$ and kept at $4{ }^{\circ} \mathrm{C}$ for the following experiments.

\section{Peroxidase activity analysis}

The catalytic reaction was performed at $25{ }^{\circ} \mathrm{C}$ using $50 \mu \mathrm{g} / \mathrm{mL} \mathrm{Ni}$-hemin MOF in a reaction volume of $1 \mathrm{~mL}$ phosphate buffer solution (PBS, $\mathrm{pH}=7$ ) containing $\mathrm{H}_{2} \mathrm{O}_{2}$ $(0.85 \mathrm{mM})$ and TMB $(1.24 \mathrm{mM})$. The absorbance and the time-dependent absorbance changes at $652 \mathrm{~nm}$ within $10 \mathrm{~min}$ were assayed. The reaction kinetics of $\mathrm{Ni}$-hemin MOF for the catalytic oxidation of TMB were studied by recording the absorption spectra with selected time interval in scanning kinetics mode. The reaction was performed at room temperature and recorded immediately after the aqueous solution containing desired concentrations of $\mathrm{H}_{2} \mathrm{O}_{2}$ and TMB mixed with $50 \mu \mathrm{g} \mathrm{mL} \mathrm{m}^{-1} \mathrm{Ni}-$ hemin MOF in phosphate buffer solution (PBS, $\mathrm{pH}=7$ ). Apparent kinetic parameters were calculated using Lineweaver-Burk plots of the double reciprocal of the Michaelis-Menten equation, $1 / \mathrm{V}=\mathrm{Km} / \mathrm{Vm}(1 /[\mathrm{S}]+1 /$ $\mathrm{Km}$ ), where $\mathrm{V}$ is the initial velocity, $\mathrm{Vm}$ represents the maximal reaction velocity, $[\mathrm{S}]$ corresponds to the concentration of substrate, and $\mathrm{Km}$ is the Michaelis constant [36].

\section{Cell culture, bioassay and cell viability evaluation}

Human breast cancer cells (MCF-7), Human Caucasian gastric adenocarcinoma (AGS) and human embryonic kidney cells (HEK 293 normal cells) were grown in Dulbecco's Modified Eagle's Medium (DMEM) cell culture medium containing $10 \%$ fetal bovine serum, penicillin $\left(100 \mathrm{U} \mathrm{mL}^{-1}\right)$, and streptomycin $\left(100 \mathrm{mg} \mathrm{mL}^{-1}\right)$ under a humidified atmosphere with $5 \% \mathrm{CO}_{2}$ at $37{ }^{\circ} \mathrm{C}$. For the colorimetric detection, cells were plated into 96-well plate at $37{ }^{\circ} \mathrm{C}$ for 1 day. After it was washed with PBS (10 mM, pH 7.4), the cells were fixed with $4 \%$ paraformaldehyde at room temperature for $10 \mathrm{~min}$. Afterward, formaldehyde was removed and the cells were again washed with PBS and allowed to incubate with $30 \mu \mathrm{L}$ of prepared FA/Ni-hemin MOF for $2 \mathrm{~h}$. Then each cell well was washed three times with phosphate buffer solution $(0.1 \mathrm{M}, \mathrm{pH}=7)$ to remove unattached $\mathrm{FA} / \mathrm{Ni}$-hemin MOF. After that, PBS $(0.1 \mathrm{M}, \mathrm{pH} 7,200 \mu \mathrm{L})$ containing TMB $(0.85 \mathrm{mM})$ and $\mathrm{H}_{2} \mathrm{O}_{2}(1.24 \mathrm{mM})$ was added to each well, and incubated for $20 \mathrm{~min}$ at room temperature. Finally, the reaction was terminated by $\mathrm{H}_{2} \mathrm{SO}_{4}(0.3 \mathrm{M})$ and quantitatively measuring were performed for color reaction. The cell viability tests were performed by the standard MTT (3-(4,5-dimethylthiazol-2-yl)-2,5-diphenyltetrazolium bromide) assay method [37]. Briefly, the cells were seeded into 96 -well plate $\left(1 \times 10^{4}\right.$ cells per well $)$ in DMEM cell culture medium. After $12 \mathrm{~h}$, the medium was replaced with fresh DMEM (100 $\mu \mathrm{L}$ per well), followed by incubation with different concentrations of $\mathrm{Ni}$ hemin MOF for another $12 \mathrm{~h}$. After washing, $\mathrm{H}_{2} \mathrm{O}_{2}(60$ or $120 \mu \mathrm{M})$ or AA ( 1 or $2 \mathrm{mM}$ ) was added for further $2 \mathrm{~h}$ of incubation. The cells were washed with PBS and then cultured for another $18 \mathrm{~h}$. After that, the medium was replaced with DMEM $(100 \mu \mathrm{L}$ per well) containing MTT $\left(0.5 \mathrm{mg} \mathrm{mL}^{-1}\right)$ followed by the incubation for $4 \mathrm{~h}$. The medium was removed and the violet frozen crystals were dissolved with DMSO $(100 \mu \mathrm{L})$. Finally, the absorbance intensity at $565 \mathrm{~nm}$ was recorded by a micro plate reader.

\section{Results and discussion}

\section{Characterization of Ni-hemin metal-organic framework}

The morphology of the as prepared Ni-hemin MOF nanocomposite was investigated by scanning electron microscopy and transmission electron microscopy (Fig. 1a-i) shows a representative SEM image, from which one can observe a hollow structure of as-prepared MOF composed of wrinkled flakes with an average length of $200 \mathrm{~nm}-1 \mu \mathrm{m}$. Linkages between nickel ions and hemin molecules as an organic ligand provide such morphology which has not yet been reported in previous works on nickel-MOF (Fig. $1 \mathrm{j}-\mathrm{m}$ ) shows a typical TEM image of Ni-hemin MOF, lots of pores on the nanostructure is clearly observed. The characterization of the prepared nanomaterial was also examined with XRD technique. XRD powder pattern of prepared sample are shown in Fig. 2a. The main diffraction peaks 


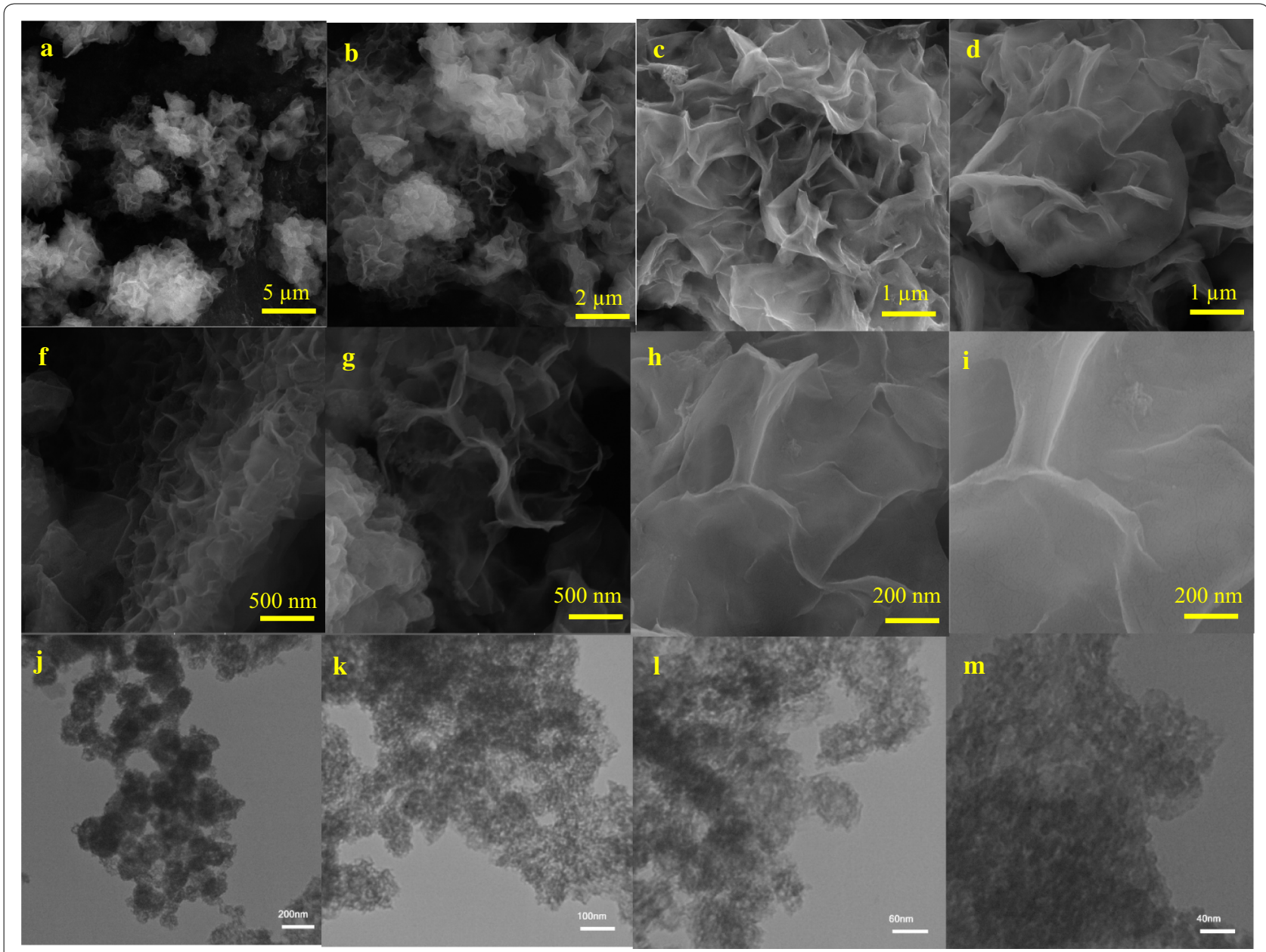

Fig. 1 a-i SEM image and $\mathbf{j}-\mathbf{m}$ TEM image of Ni-hemin MOF nanocomposite with different magnitude

of the as-prepared MOF samples appeared at approximately $17.9^{\circ}, 26.18^{\circ}, 27.97^{\circ}, 30.33^{\circ}, 35.61^{\circ}, 39.53^{\circ}, 43.93^{\circ}$, $53.02^{\circ}, 60.30$ and $71.78^{\circ}$. The results indicated the as-prepared MOFs material has crystal structure.

X-ray photoelectron spectroscopy (XPS) was also accomplished to investigate the chemical states of bonded elements in the as- prepared sample. As can be seen from Fig. $2 b$, the survey XPS spectra display a set of peaks corresponding with $\mathrm{C} 1 \mathrm{~s}, \mathrm{O} 1 \mathrm{~s}$, and Ni2p spectra, respectively. It should be noted that $\mathrm{C} 1 \mathrm{~s}(285.08 \mathrm{eV})$ is ascribed to a carbon-based substrate, while the peak at $531.08 \mathrm{eV}, 711.98 \mathrm{eV}$ and $855.37 \mathrm{eV}$ are attributed to $\mathrm{O} 1 \mathrm{~s}, \mathrm{Fe} 2 \mathrm{p}$ and Ni2p spectra, respectively. Figure 2c shows the highly resolved narrow scans Ni $2 p$ spectra of $\mathrm{Ni}$-hemin MOFs, the $\mathrm{Ni} 2 \mathrm{p}_{3 / 2}$ peak at $855.37 \mathrm{eV}$ are from $\mathrm{Ni}^{2+}$ and are associated with the $\mathrm{Ni}-\mathrm{O}$ octahedral bonding of cubic Ni-hemin [38]. The high-resolution Fe 2p XPS spectrum revealed that curve-fitted into two peaks (Fig. 2d), the peak at 711.98 is relating to $\mathrm{Fe}^{3+}$ of hemin in Ni-hemin MOF. The Ni and Fe content in Ni-hemin
MOFs was 13.38 and $6.19 \%$, respectively, based on XPS. The EDS analysis of Ni-hemin MOFs also clearly revealed their elemental composition and corroborated the presence of $\mathrm{Ni}$ and $\mathrm{Fe}$ in prepared nanocomposite (Fig. 3A). TGA analysis further executed and the result shown in Fig. 3B. Typically, TGA curve shows a little weight loss peak at the temperature range of $35-170{ }^{\circ} \mathrm{C}$ and an obvious peak at $170-650{ }^{\circ} \mathrm{C}$. The weight losses corresponding to the two steps in TGA are about 8.43 and $37.71 \%$, respectively. The first weight loss ascribes to the removal of structural water, and the second due to the removal of carbon structure of hemin. FT-IR spectra can provide some useful information on the structure of $\mathrm{Ni}$ hemin MOFs nanocomposite. Figure $3 \mathrm{C}$ shows the comparative FT-IR spectra of Ni-hemin MOFs and FA/ Ni-hemin MOFs nanocomposite. As shown in curve a, the FT-IR spectra of Ni-hemin MOFs shows the peaks at $3419 \mathrm{~cm}^{-1}$ and $2924 \mathrm{~cm}^{-1}$ originated from $\mathrm{O}-\mathrm{H}$ and $\mathrm{C}-\mathrm{H}$ of hemin. The absorption band assigned to the $\mathrm{C}=\mathrm{O}$ stretch mode of carboxylic group at $1633 \mathrm{~cm}^{-1}$, 

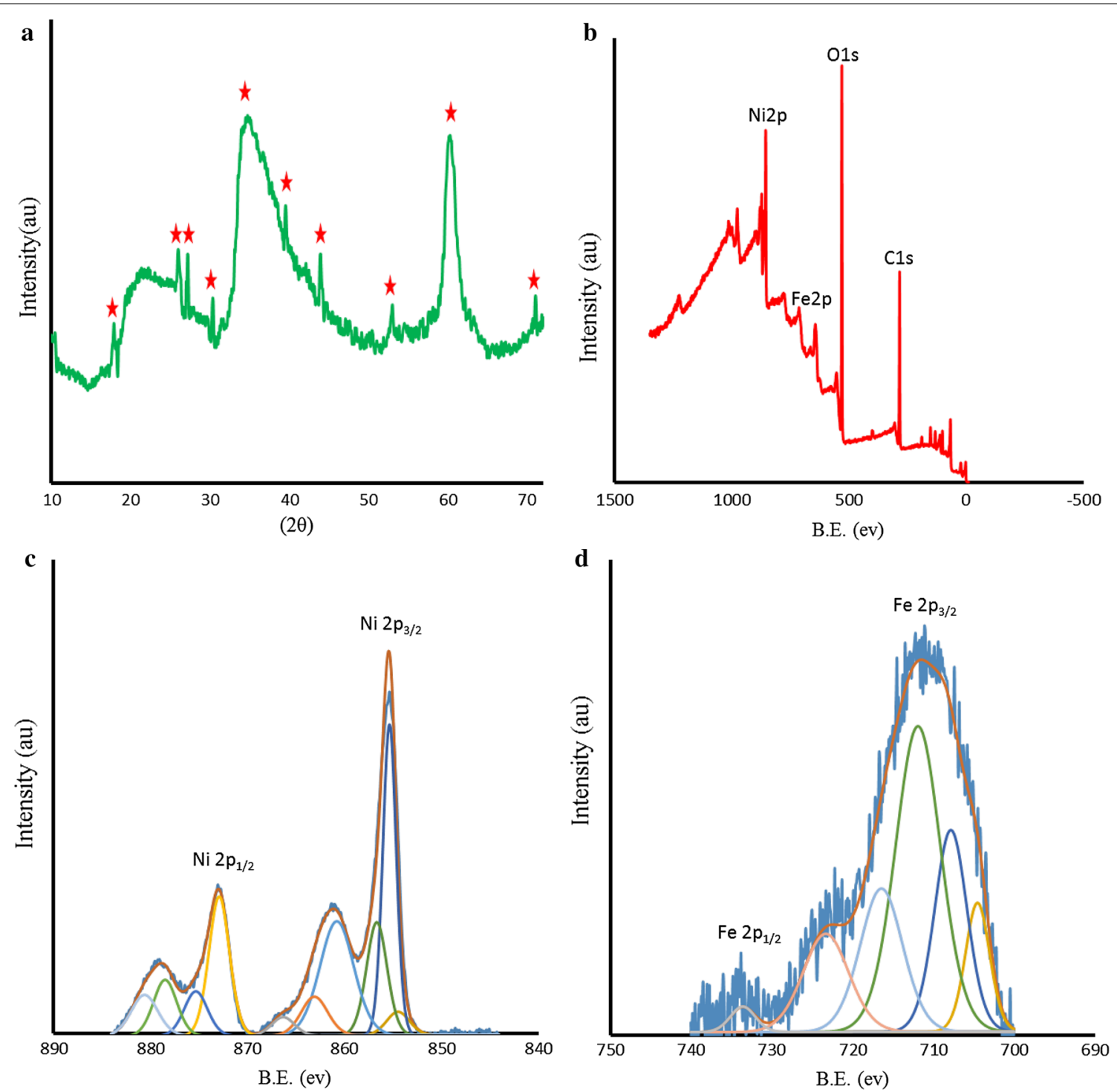

Fig. 2 a XRD patterns of the Ni-hemin MOF nanocomposite, $\mathbf{b}$ XPS survey, c Ni $2 p$ spectra and $\mathbf{d}$ Fe $2 p$ spectra of the Ni-hemin MOF nanocomposite

an absorption band at $1466,1381 \mathrm{~cm}^{-1}$ and $1005 \mathrm{~cm}^{-1}$ attributed to the $\mathrm{B} 3 \mathrm{u}$ vibration of porphyrin, $=\mathrm{C}-\mathrm{H}$ deformation vibration of olefin and $-\mathrm{CH}_{3}$ of hemin, which confirm the successful formation of porphyrinicMOF nanocomposite [39]. After immobilization of folic acid on the nanocomposite via APTES (curve b), the characteristic and absorption at $519 \mathrm{~cm}^{-1}$ for vibrations from $\mathrm{Ni}-\mathrm{Si}-\mathrm{O}$ has appeared which, attributed to the conjugation of APTES. Furthermore, the absorption band of carboxylic group was stronger in comparison with $\mathrm{Ni}$-hemin MOFs, confirming successful modification of nanocomposite with folic acid. $\mathrm{N}_{2}$ adsorption-desorption isotherms measurements were performed to investigate the porosity of the obtained Ni-hemin MOFs. As can be seen from Fig. 4a the isotherms of Ni-hemin MOFs shows a typical IV isotherm contained a hysteresis loop, which indicates the being of different pore sizes distribution ranged from micro-to mesopores [40]. Figure $2 b$ also shows pore diameter distribution of nanocomposite which is mainly $1.91,2.38$ and $3.31 \mathrm{~nm}$.

\section{Peroxidase-like activity of Ni-hemin MOFs}

To demonstrate that Ni-hemin MOFs is an ideal biomimetic catalyst, we evaluated the peroxidase-like activity of Ni-hemin MOFs by catalytic oxidation of the common peroxidase substrate, $\mathrm{TMB}$, in the presence of 

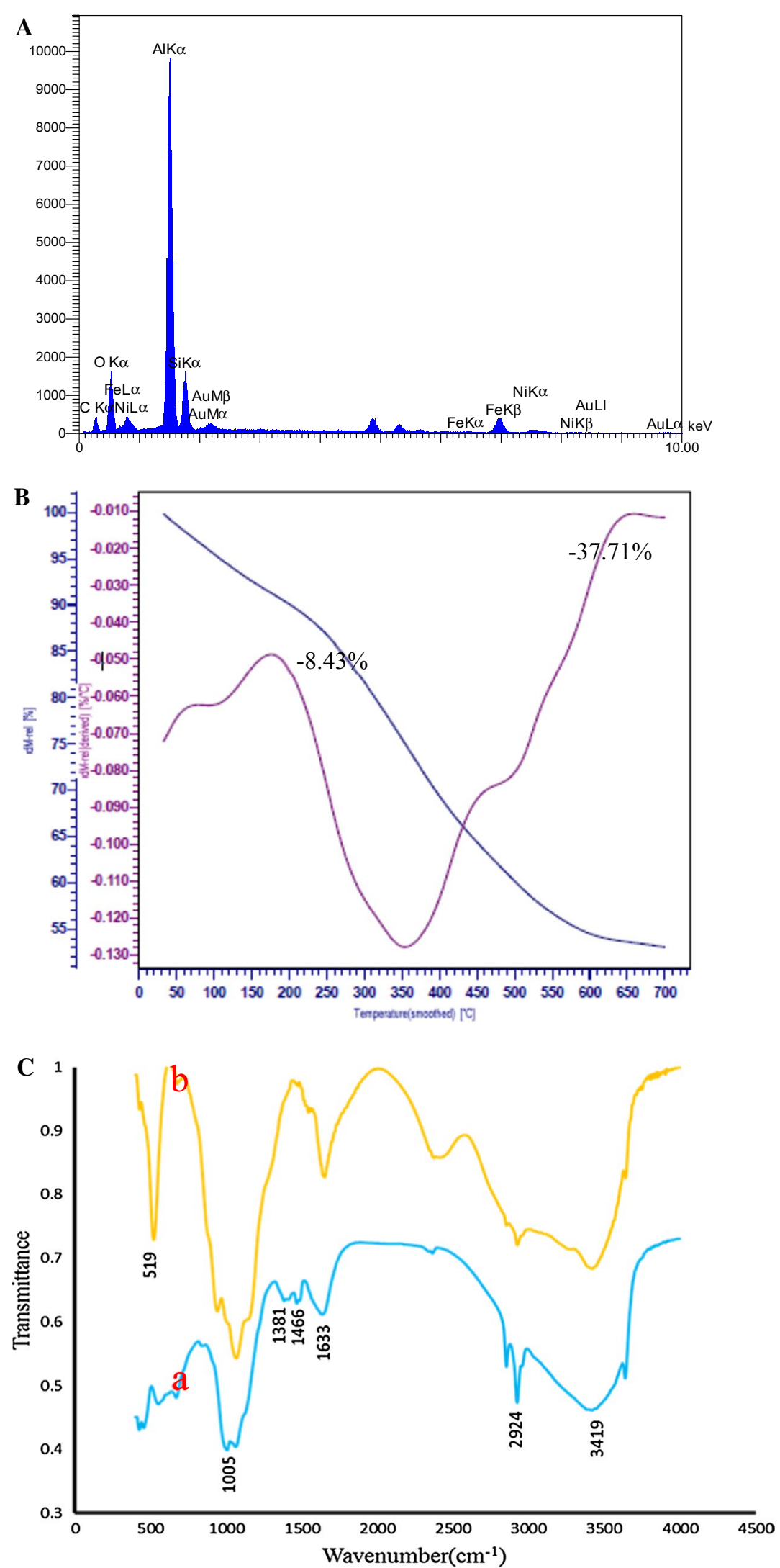

Fig. 3 A EDS spectra, B TGA curve, and C FTIR of Ni-hemin MOF nanocomposite 


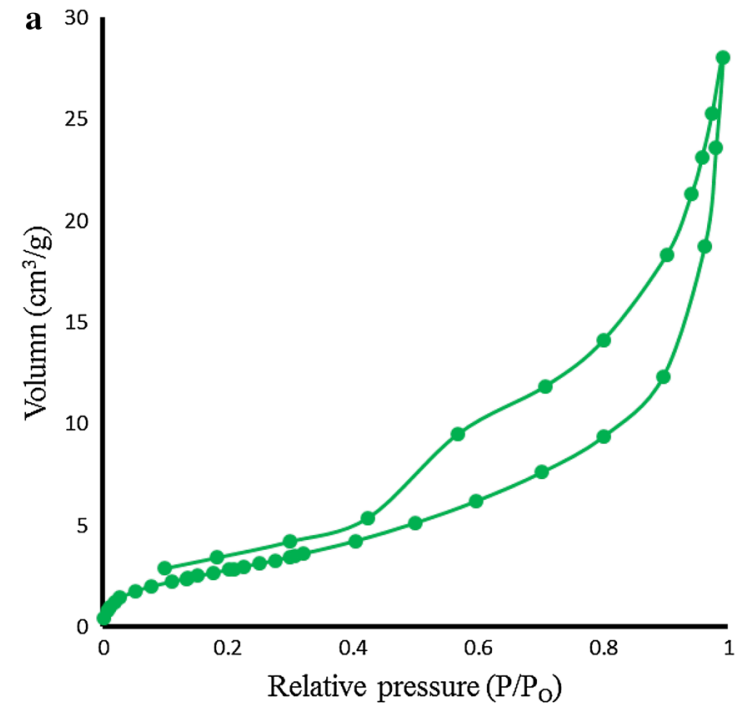

Fig. 4 a N2 adsorption-desorption isotherm and $\mathbf{b}$ pore distribution

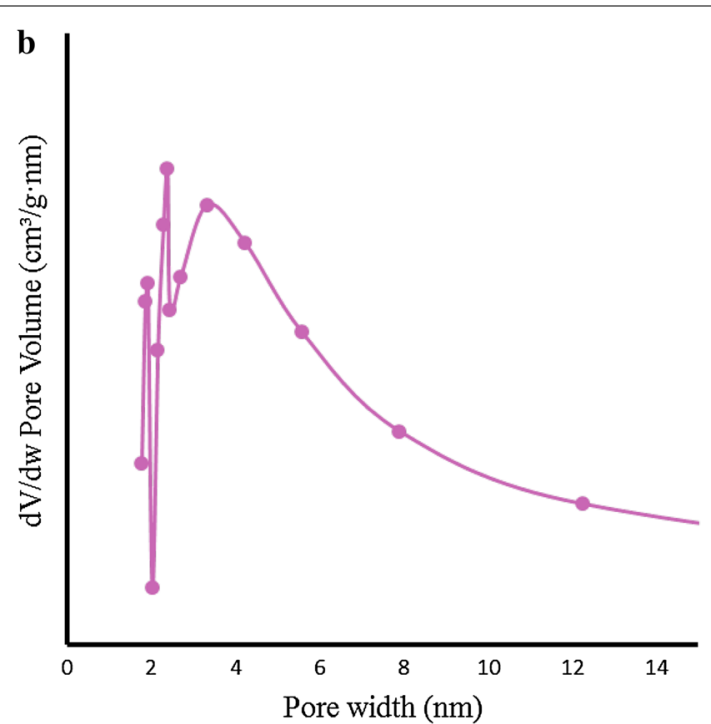

$\mathrm{H}_{2} \mathrm{O}_{2}$ (Fig. 5A). As can be observed in UV-vis spectra and photographs, the Ni-hemin MOFs aqueous solutions exhibited almost no color change without $\mathrm{H}_{2} \mathrm{O}_{2}$ and TMB, although an absorption peak at $400 \mathrm{~nm}$ indicated the presence of hemin in nanocomposite (curve a). When solution of TMB and $\mathrm{H}_{2} \mathrm{O}_{2}$ was introduced into the Ni-hemin MOFs, a typical blue color appeared in the solution (curve b). The new absorption peaks appeared at $650 \mathrm{~nm}$ and $373 \mathrm{~nm}$ which is attributed to the charge-transfer complexes derived from the one electron oxidation of TMB (TMB ox) [41] and the intensity of these peaks increased with increasing of reaction time (Fig. 5B).

Upon addition of $\mathrm{H}_{2} \mathrm{SO}_{4}$, the color of solution turned to yellow and absorption peak was observed at $450 \mathrm{~nm}$ (Fig. 5A, curve c). Comparison experiments with (a) Ni-hemin MOFs (b) TMB and $\mathrm{H}_{2} \mathrm{O}_{2}$ (c) Ni-hemin MOFs + TMB and $\mathrm{H}_{2} \mathrm{O}_{2}$ were performed by measuring the time-dependent absorbance at $652 \mathrm{~nm}$ (Fig. 5c), the significant peroxidase catalytic activity was observed for Ni-hemin MOFs. It was found that the catalytic activity increased with increasing the amount of the Ni-hemin MOFs nanocomposite (Fig. 5D). The apparent steadystate kinetic parameters for the peroxidase- like enzymatic color reaction were determined by varying the concentrations of TMB and $\mathrm{H}_{2} \mathrm{O}_{2}$ in the system. Typical Michaelis-Menten curves can be obtained for the Ni-hemin MOFs with both TMB and $\mathrm{H}_{2} \mathrm{O}_{2}$ (Fig. 6a, b). Firstly, time scanning curves was obtained with a UV-Vis spectrophotometer at the wavelength of $652 \mathrm{~nm}$, then, a set of initial velocities calculated and converted with molar absorption coefficient of TMB oxidation products $\left(\varepsilon 652 \mathrm{~nm}=3.9 \times 104 \mathrm{M}^{-1} \mathrm{~cm}^{-1}\right)$ [42]. Typical double reciprocal plots, $1 / v$ vs. $1 /[\mathrm{S}]$ (Fig. $6 \mathrm{a}$, b insets), were constructed and fitted to the Michaelis-Menten equation to calculate the catalytic parameters $\mathrm{Km}$ and $\mathrm{Vm}$ given in Table 1 . The Michaelis constants $(\mathrm{Km})$ of the Ni-hemin MOFs for TMB and $\mathrm{H}_{2} \mathrm{O}_{2}$ were determined to be $0.006 \mathrm{mM}$ and $2.31 \mathrm{mM}$, respectively. In comparison with the natural enzyme HRP the Ni-hemin MOFs have a relatively lower $\mathrm{Km}$ value for TMB and $\mathrm{H}_{2} \mathrm{O}_{2}$, which indicate (Km for HRP) the higher affinity of the proposed MOF compared to natural HRP. So, peroxidase-like Nihemin MOFs shows relatively high affinity for both TMB and $\mathrm{H}_{2} \mathrm{O}_{2}$.

\section{Colorimetric detection of cancer cells}

In our investigations, FA/Ni-hemin MOF with superior peroxidase activity was used as the signal indicator for cancer cell detection. As aforesaid, selective targeting of hybrid material with cancerous cells occurs through attached FA targeting ligand [43]. TMB as substrate agent molecule lost one electron and transformed into the status of cation radical, then the colorless solution turned to blue color. Then the oxidation reaction stopped by $\mathrm{H}_{2} \mathrm{SO}_{4}$ leading to the cation radical of TMB molecule, which further lost another electron to form diamine, and the blue solution changed to be yellow [44]. This working principle is demonstrated in Fig. 7. Herein, we chose human breast cancer cells (MCF-7) and Caucasian gastric adenocarcinoma (AGS) expressing folate receptors on the cell membrane, and a normal cell line human embryonic kidney cells (HEK 293) with lack of folate receptors as a control [45]. The four samples are as follow: $30 \mu \mathrm{L}$ of 

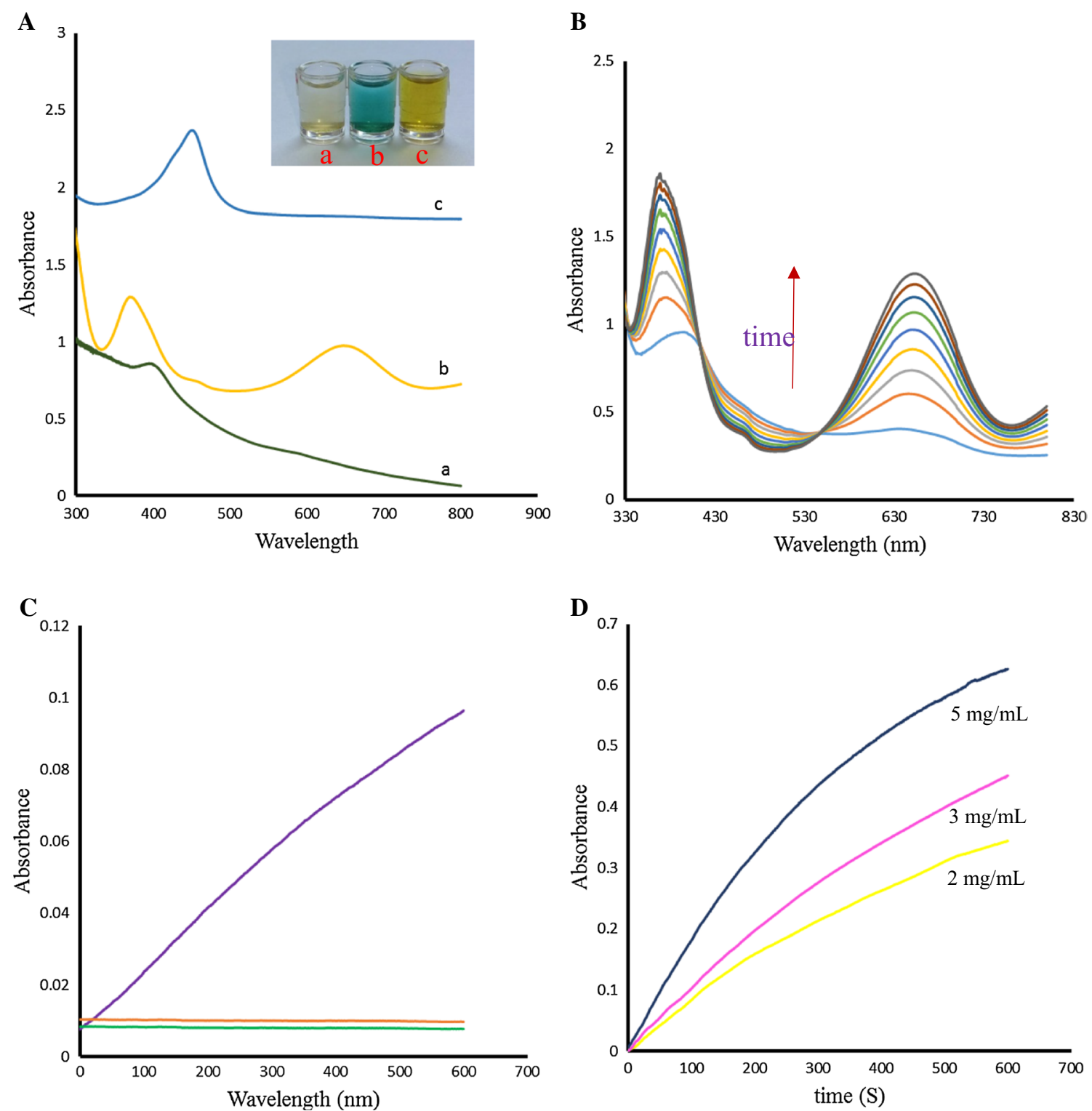

Fig. 5 A UV-vis and photographs of (a) Ni-hemin MOF solution (b) Ni-hemin MOF +TMB $+\mathrm{H}_{2} \mathrm{O}_{2}$ (c) Ni-hemin MOF $+\mathrm{TMB}^{2}+\mathrm{H}_{2} \mathrm{O}_{2}+\mathrm{H}_{2} \mathrm{SO}_{4}$, B Time-dependent UV-vis spectral changes of TMB solution with $\mathrm{H}_{2} \mathrm{O}_{2}$ catalyzed by NiO MOF, C Time-dependent absorbance changes of (a) Ni-hemin MOF solution (b) TMB $+\mathrm{H}_{2} \mathrm{O}_{2}$ (c) Ni-hemin MOF $+\mathrm{TMB}+\mathrm{H}_{2} \mathrm{O}_{2}$ at $652 \mathrm{~nm}$, and D Time-dependent absorbance changes of TMB solution with $\mathrm{H}_{2} \mathrm{O}_{2}$ at $652 \mathrm{~nm}$ in the presence of different concentrations of $\mathrm{NiO}$ MOF

FA/Ni-hemin MOF with no cells, $30 \mu \mathrm{L}$ of FA/Ni-hemin MOF with 3200 HEK 293, $30 \mu \mathrm{L}$ of FA/Ni-hemin MOF with 3200 AGS cells, $30 \mu \mathrm{L}$ of FA/Ni-hemin MOF with 3200 MCF-7 cells. After the addition of TMB- $\mathrm{H}_{2} \mathrm{O}_{2}$ and subsequently $\mathrm{H}_{2} \mathrm{SO}_{4}$ solution, the specific generation of yellow color was observed in the case of MCF-7 and AGS cells, whereas for the wells containing HEK 293 cell and buffer medium without any cell lines, no significant color change was observed (Fig. 8a). These results indicate that the FA functionalized Ni-hemin MOF (FA/ 

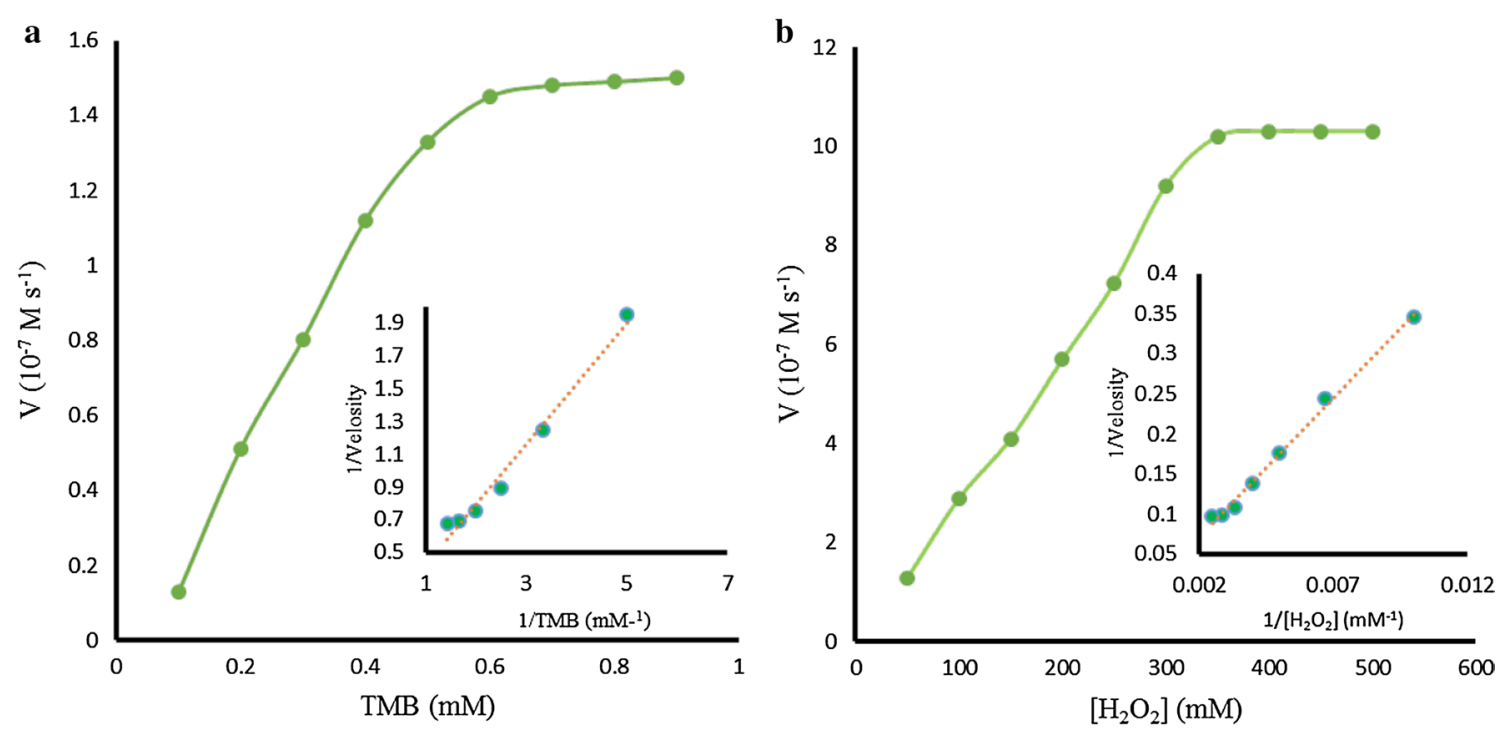

Fig. 6 Steady-state kinetic analyses using the Michaelis-Menten model and Lineweaver-Burk model (insets) for Ni-hemin MOF nanocomposite by a varying the concentration of TMB with a fixed amount of $\mathrm{H}_{2} \mathrm{O}_{2}$ and $\mathbf{b}$ varying the concentration of $\mathrm{H}_{2} \mathrm{O}_{2}$ with a fixed amount of TMB

Table 1 Kinetic Parameters of Ni-hemin MOF hybrid and HRP Obtained from Their Corresponding MichaelisMenten Curves

\begin{tabular}{llll}
\hline Catalyst & Substance & $\begin{array}{l}\text { Km } \\
(\mathbf{m M})\end{array}$ & $\begin{array}{l}\text { Vmax } \\
\left(\times \mathbf{1 0}^{\mathbf{- 7}} \mathbf{M} \cdot \mathbf{s}^{-\mathbf{1}}\right)\end{array}$ \\
\hline Ni-hemin MOFs & $\mathrm{TMB}$ & 0.006 & 18.51 \\
Ni-hemin MOFs & $\mathrm{H}_{2} \mathrm{O}_{2}$ & 2.31 & 36.66 \\
HRP & $\mathrm{TMB}$ & 0.43 & 10 \\
HRP & $\mathrm{H}_{2} \mathrm{O}_{2}$ & 3.70 & 8.7 \\
\hline
\end{tabular}

$\mathrm{Ni}$-hemin MOF) is a good recognition element and could differentiate between target cells and control cells. Moreover, because of the different amounts of folate receptor expression on different types of cancer cells, more FA/Nihemin MOF nanocomposites are bound to MCF-7 cells more than AGS cells. To further evaluate the capability of the hybrid for calorimetrically differentiate between different numbers of cancer cells, a suitable amount of $\mathrm{FA} / \mathrm{Ni}$-hemin MOF was incubated with various concentrations of MCF-7 cells in a 96 well plate. Figure 8b, c shows the image of color variation and UV-vis absorbance changes at $450 \mathrm{~nm}$ and the image of color variation in the presence of varying amounts of MCF-7 cells. Color variation of TMB oxidation and the absorbance change at $450 \mathrm{~nm}$ is proportional to the number of MCF-7 cells over a range of $50-10^{5}$ cells. This color change of the solution was obvious and easily observed by the nakedeye. The assay has appropriate sensitivity to cancer cells, the limit of detection of MCF-7 cells was calculated to be 10 cells, which is lower than that of previously reported cancer cell detection [46-48]. Thus, the proposed diagnostic system based on $\mathrm{FA} / \mathrm{Ni}$-hemin MOF probe is a rapid, cost-effective, sensitive and selective method for the accurate and early detection of cancer cells.

\section{Cell viability assay (MTT assay)}

Previous studies shown that the nanozymes with peroxidase-like activity could generate strong oxidant. $\mathrm{OH}$ via decomposition of $\mathrm{H}_{2} \mathrm{O}_{2}$ [49]. According to this phenomenon, we utilized Ni-hemin MOF nanocomposites for therapeutic treatment of cancer cells based on its efficient generation of $\mathrm{OH} \bullet$ radical through the peroxidase activity. Therefore, to evaluate anticancer activity, we incubated various concentrations of Ni-hemin MOF (7-60 $\mu \mathrm{g} \mathrm{mL}^{-1}$ ) with MCF-7 cells for $12 \mathrm{~h}$. Firstly, inherent toxicity of nanocomposite was measured using MTT 


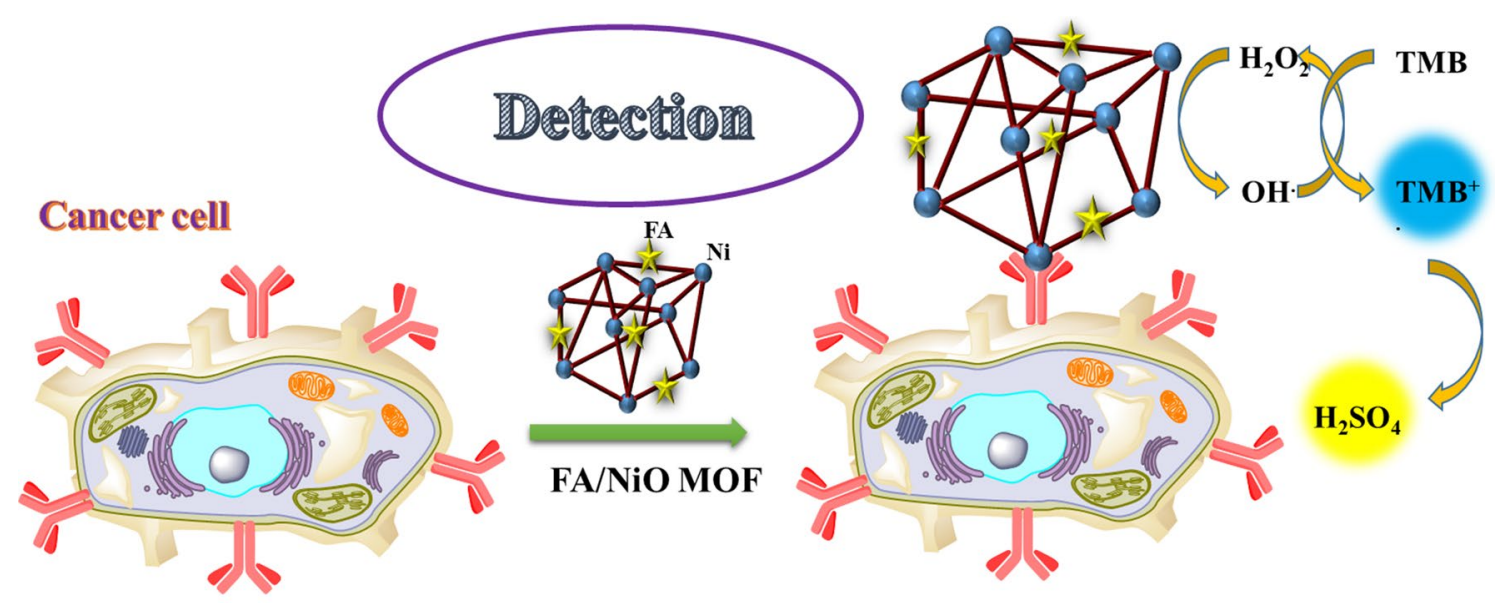

\section{Live cell}

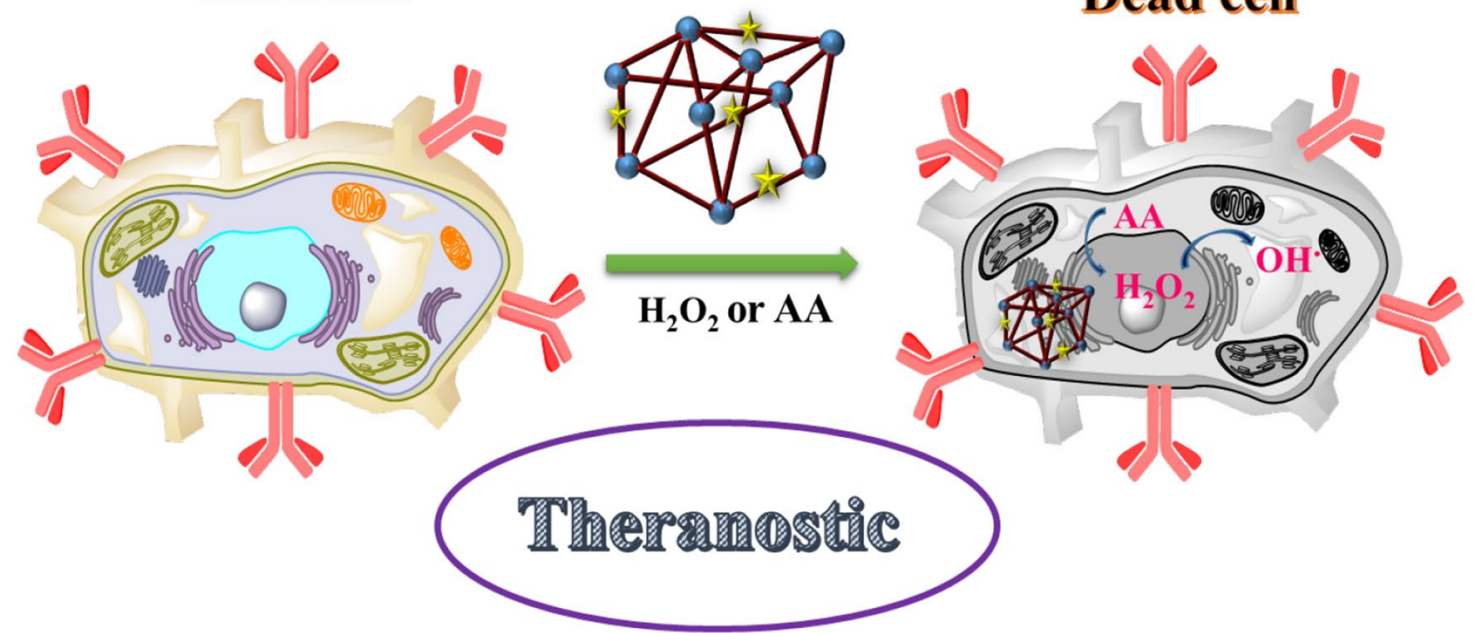

Fig. 7 Schematic illustration of peroxidase activity of Ni-hemin MOF for cancer cell detection

(3-(4,5-dimethylthiazol-2-yl)-2,5-diphenyltetrazolium bromide) assay, showing a slight cytotoxicity [50]. Then, $\mathrm{H}_{2} \mathrm{O}_{2}(90$ or $160 \mu \mathrm{M})$ was added into the cell lines, and the cell viability was investigated. As shown in Fig. 9a, with increasing concentration of both Ni-hemin MOF and $\mathrm{H}_{2} \mathrm{O}_{2}$ the cell viability significantly decreased up to $\sim 18 \%$. indicating the promising anticancer capability of the prepared nanocomposite. Ascorbic acid (AA) as an antioxidant could produces endogenous $\mathrm{H}_{2} \mathrm{O}_{2}$ to result in generation of oxidant.OH. So, in this research, instead of using exogenous $\mathrm{H}_{2} \mathrm{O}_{2}, 1$ or $2 \mathrm{mM}$ AA was applied along with Ni-hemin MOF (7-60 $\left.\mu \mathrm{g} \mathrm{mL}^{-1}\right)$ to evaluate the cancer treatment strategy. As displayed in Fig. 9b, the cell viability decreased remarkably to $\sim 29 \%$ in the presence of Ni-hemin MOF and AA in a concentration dependent manner. To check the targeted therapeutic ability of the nanocomposite to effect only the cancer cells, normal HEK 293 cells were also treated under same conditions and the cell viability was determined. Compared to cancer cells a minor cytotoxicity was determined for $\mathrm{Ni}$ hemin MOF along with $\mathrm{H}_{2} \mathrm{O}_{2}(\sim 31 \%$ cell death at high concentration) and AA ( $\sim 28 \%$ cell death at high concentration), respectively (Figure 9c, d). This result implicating the selective targeting ability of the nanocomposite to MCF-7 cancer cells through the FA targeting ligand. 


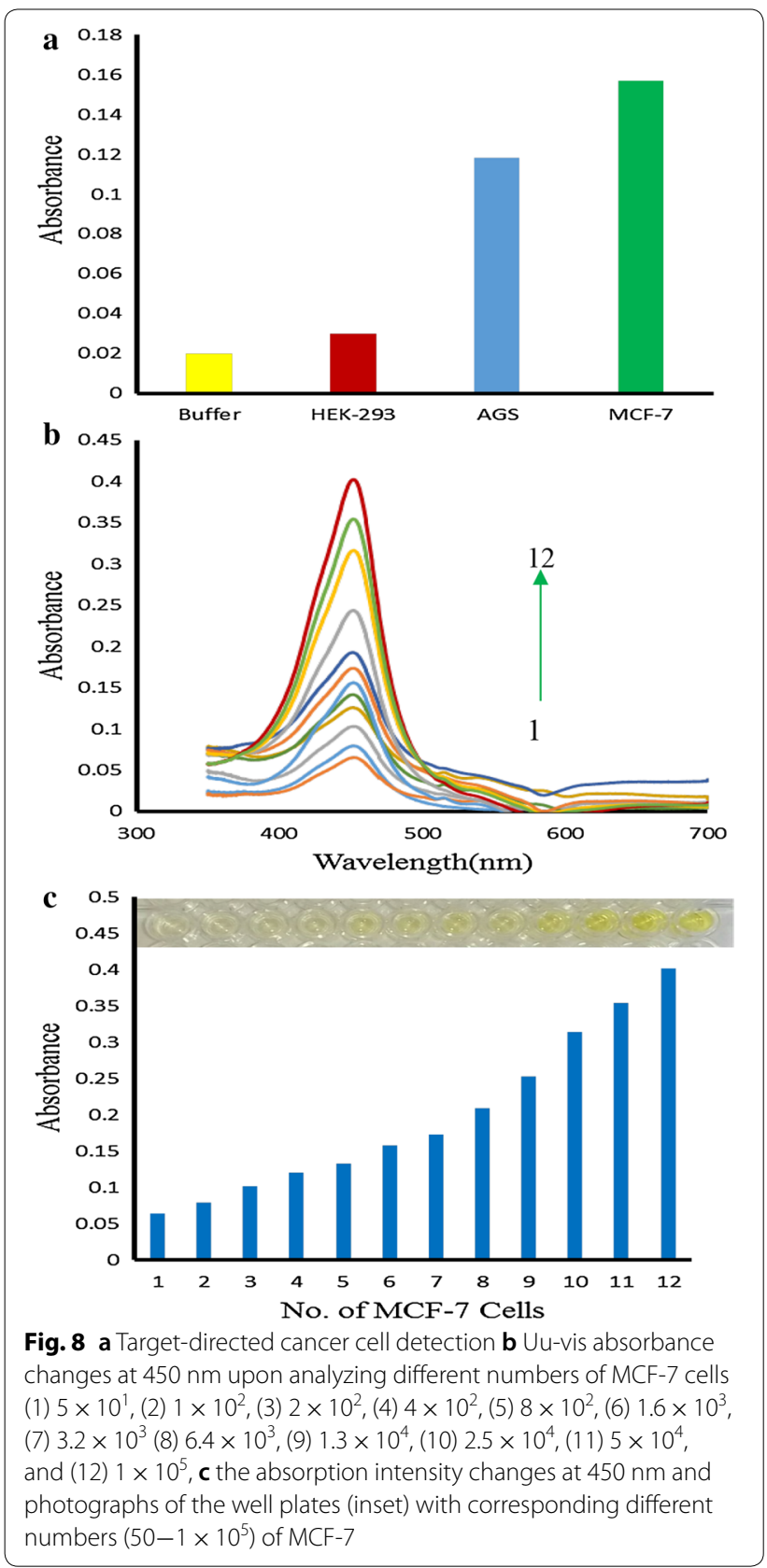

\section{Conclusions}

In this work, we have obtained the new kind of metal organic framework nanostructure (Ni-hemin MOF) via simple process and demonstrated that Ni-hemin MOF nanocomposites possess high intrinsic peroxidase-like activity. Peroxidase-like activity of Ni-hemin MOFs was investigated by catalytic oxidation of the common peroxidase substrate, TMB, in the presence of $\mathrm{H}_{2} \mathrm{O}_{2}$ (Fig. 4). Ni-hemin MOFs could oxidize TMB in the presence of $\mathrm{H}_{2} \mathrm{O}_{2}$ and produce color solution. Apparent kinetic parameters were obtained using LineweaverBurk plots of the double reciprocal of the Michaelis-Menten equation, $1 / \mathrm{V}=\mathrm{Km} / \mathrm{Vm}(1 /[\mathrm{S}]+1 / \mathrm{Km})$ (Fig. 5). Ni-hemin have a relatively lower $K m$ value for both substrate TMB and $\mathrm{H}_{2} \mathrm{O}_{2}$. As compared to natural enzymes, Ni-hemin MOF have several advantages such as low-cost and high-stability and very high substratebinding affinity as compared to HRP. On the basis of folic acid ability to recognize elements, the excellent peroxidase activity of Ni-hemin MOF has been utilized for the colorimetric detection of cancer cells. The selective binding Ni-hemin MOF cause significant color change by the oxidation of TMB in the presence $\mathrm{H}_{2} \mathrm{O}_{2}$ for MCF-7 cancer cell detection with a detection limit of 10 cells, which could be also distinguished by the naked eye. Thereby, the prepared FA/Ni-hemin MOF enabled quick colorimetric analysis to give a quantitative and accurate results (Fig. 8). Attractive properties of the novel MOF nanocomposite would be significant to propel the development of novel peroxidase mimics materials. Moreover, this study will facilitate utilization of other recognition elements such as aptamers, antibody, peptide, and nucleic acid to design and develop colorimetric assays in clinical diagnostics and biotechnology. Because of advances in early detection and treatment, the number of cancer survivors continues to grow in the world. Ni-hemin MOF in addition to diagnostic ability, represents a therapeutic activity and significant cancer cell damage was observed through the enhanced generation of $\mathrm{OH}$ - radical from exogenous and endogenous $\mathrm{H}_{2} \mathrm{O}_{2}$ mediated by Ni-hemin MOF 

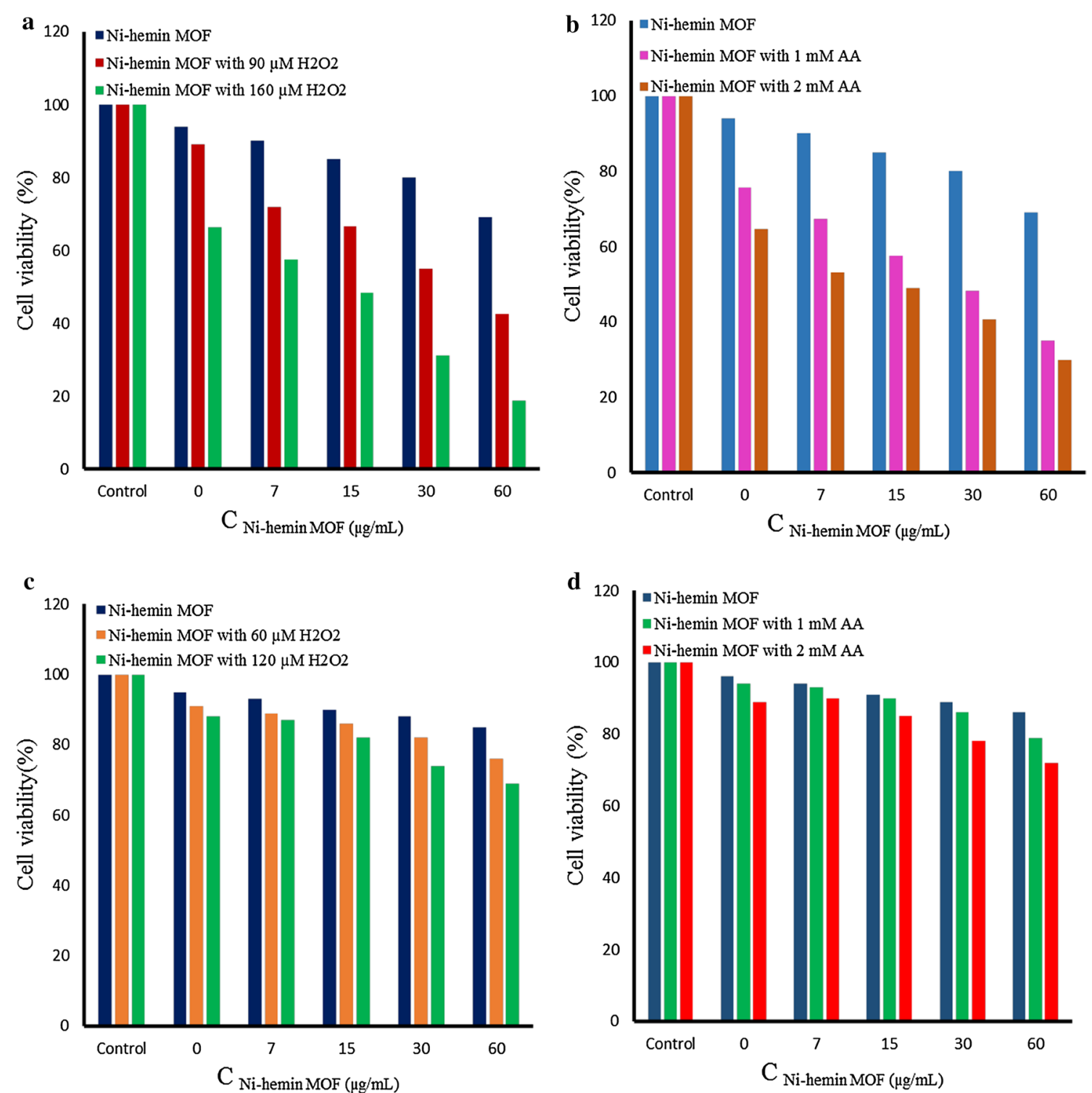

Fig. 9 a Cell viability tests by MTT assay for MCF-7 cells in the presence of (a) Ni-hemin MOF with $\mathrm{H}_{2} \mathrm{O}_{2}$ ( 90 or $160 \mu \mathrm{M}$ ) and $\mathbf{b} \mathrm{Ni}$-hemin MOF with AA (1 or 2 mM). c HEK-293 cell viability upon treatment by Ni-hemin MOF with $\mathrm{H}_{2} \mathrm{O}_{2}(90$ or $160 \mu \mathrm{M}$ ) and $\mathbf{d}$ Ni-hemin MOF with AA (1 or 2 mM)

(Fig. 9). OH• radical as a reactive oxygen species (ROS) causes the damage of cancer cells, however the normal cells have the capability to endure a certain level of exogenous ROS stress. High selectivity of both the detection and therapeutic processes to cancer cell signifying robustness and efficiency of the method.

\section{Abbreviations}

MOF: metal-organic framework; CTAB: cetrimonium bromide; TMB: 3,3',5,5'tetramethylbenzidine; FA: folic acid; APTES: (3-Aminopropyl) triethoxysilane; SEM: scanning electron microscopy; TEM: transmission electron microscopy; XRD: X-ray diffraction; XPS: X-ray Photoelectron Spectroscopy; MCF-7: human breast cancer cells; HEK: human embryonic kidney cells; AGS: Human Caucasian gastric adenocarcinoma.

\section{Authors' contributions}

AS, RH and FF conceived and designed the experiments. NA and FS performed the experiments. NA wrote the paper with support from AS. All authors contributed to the general discussion. All authors read and approved the final manuscript.

\section{Author details}

${ }^{1}$ Department of Chemistry, University of Kurdistan, 66177-15175 Sanandaj, Iran. ${ }^{2}$ Research Center for Nanotechnology, University of Kurdistan, 66177-15175 Sanandaj, Iran. ${ }^{3}$ Cellular and Molecular Reserch Center, Kurdistan University of Medical Sciences, 66177-13446 Sananandaj, Iran. 


\section{Acknowledgements}

We gratefully acknowledge central laboratory of University of Kurdistan for the technical supports.

\section{Competing interests}

The authors declare that they have no competing interests.

\section{Availability of data and materials}

All data generated or analyzed during this study are included in the article.

\section{Consent for publication}

All authors have provided consent for the manuscript to be published.

\section{Funding}

This work is financially supported by the Research Office of University of Kurdistan (grant number 4.1261) and Iranian Nanotechnology initiative.

\section{Publisher's Note}

Springer Nature remains neutral with regard to jurisdictional claims in published maps and institutional affiliations.

Received: 19 July 2018 Accepted: 7 November 2018

Published online: 20 November 2018

\section{References}

1. Alizadeh N, Hallaj R, Salimi A. A highly sensitive electrochemical immunosensor for hepatitis $B$ virus surface antigen detection based on Hemin/G-quadruplex horseradish peroxidase-mimicking DNAzymesignal amplification. Biosens Bioelectron. 2017;94:184-92.

2. Alizadeh N, Hallaj R, Salimi A. Dual amplified electrochemical immunosensor for hepatitis B virus surface antigen detection using hemin/Gquadruplex immobilized onto Fe3O4-AuNPs or (Hemin-Amino-rGO-Au) nanohybrid. Electroanalysis. 2018;30:402-14.

3. Alizadeh N, Salimi A, Hallaj R. Mimicking peroxidase activity of $\mathrm{CO}_{2}(\mathrm{OH})_{2}$ $\mathrm{CO}_{3}-\mathrm{CeO}_{2}$ nanocomposite for smartphone based detection of tumor marker using paper-based microfluidic immunodevice. Talanta 2018.

4. Jia H, Yang D, Han X, Cai J, Liu H, He W. Peroxidase-like activity of the Co 3 O 4 nanoparticles used for biodetection and evaluation of antioxidant behavior. Nanoscale. 2016;8:5938-45.

5. Gao L, Zhuang J, Nie L, Zhang J, Zhang Y, Gu N, Wang T, Feng J, Yang D, Perrett $S$. Intrinsic peroxidase-like activity of ferromagnetic nanoparticles. Nat Nanotechnol. 2007;2:577.

6. Zhao $\mathrm{H}$, Dong Y, Jiang P, Wang G, Zhang J. Highly dispersed $\mathrm{CeO}_{2}$ on $\mathrm{TiO}_{2}$ nanotube: a synergistic nanocomposite with superior peroxidase-like activity. ACS Appl Mater Interfaces. 2015;7:6451-61.

7. Zhang Z, Hao J, Yang W, Lu B, Ke X, Zhang B, Tang J. Porous $\mathrm{CO}_{3} \mathrm{O}_{4}$ nanorods-reduced graphene oxide with intrinsic peroxidase-like activity and catalysis in the degradation of methylene blue. ACS Appl Mater Interfaces. 2013;5:3809-15.

8. Liu X, Wang Q, Zhao H, Zhang L, Su Y, Lv Y. BSA-templated $\mathrm{MnO}_{2}$ nanoparticles as both peroxidase and oxidase mimics. Analyst. 2012;137:4552-8.

9. Lin T, Zhong L, Guo L, Fu F, Chen G. Seeing diabetes: visual detection of glucose based on the intrinsic peroxidase-like activity of MoS 2 nanosheets. Nanoscale. 2014;6:11856-62.

10. Chen W, Chen J, Feng Y-B, Hong L, Chen Q-Y, Wu L-F, Lin X-H, Xia X-H. Peroxidase-like activity of water-soluble cupric oxide nanoparticles and its analytical application for detection of hydrogen peroxide and glucose. Analyst. 2012;137:1706-12.

11. Lin L, Song $X$, Chen $Y$, Rong $M$, Zhao T, Wang $Y$, Jiang $Y$, Chen X. Intrinsic peroxidase-like catalytic activity of nitrogen-doped graphene quantum dots and their application in the colorimetric detection of $\mathrm{H}_{2} \mathrm{O}_{2}$ and glucose. Anal Chim Acta. 2015;869:89-95.

12. Lu C, Liu X, Li Y, Yu F, Tang L, Hu Y, Ying Y. Multifunctional janus hematite-silica nanoparticles: mimicking peroxidase-like activity and sensitive colorimetric detection of glucose. ACS Appl Mater Interfaces. 2015;7:15395-402.
13. Zhang J-W, Zhang H-T, Du Z-Y, Wang X, Yu S-H, Jiang H-L. Water-stable metal-organic frameworks with intrinsic peroxidase-like catalytic activity as a colorimetric biosensing platform. Chem Commun. 2014;50:1092-4.

14. Dong MJ, Zhao M, Ou S, Zou C, Wu CD. A luminescent dye@ MOF platform: emission fingerprint relationships of volatile organic molecules. Angew Chem. 2014;126:1601-5.

15. Wang S, Deng W, Yang L, Tan Y, Xie Q, Yao S. Copper-based metal-organic framework nanoparticles with peroxidase-like activity for sensitive colorimetric detection of Staphylococcus aureus. ACS Appl Mater Interfaces. 2017:9:24440-5.

16. Calleja G, Sanz R, Orcajo G, Briones D, Leo P, Martínez F. Copper-based MOF-74 material as effective acid catalyst in Friedel-Crafts acylation of anisole. Catal Today. 2014;227:130-7.

17. Yang G-S, Lang Z-L, Zang H-Y, Lan Y-Q, He W-W, Zhao X-L, Yan L-K, Wang $X-L$, Su Z-M. Control of interpenetration in S-containing metal-organic frameworks for selective separation of transition metal ions. Chem Commun. 2013;49:1088-90.

18. Stavila V, Talin AA, Allendorf M. MOF-based electronic and opto-electronic devices. Chem Soc Rev. 2014;43:5994-6010.

19. Cai W, Chu CC, Liu G, Wáng YXJ. Metal-organic framework-based nanomedicine platforms for drug delivery and molecular imaging. Small. 2015;11:4806-22.

20. Zhang M, Feng G, Song Z, Zhou Y-P, Chao H-Y, Yuan D, Tan TT, Guo Z, Hu $Z$, Tang BZ. Two-dimensional metal-organic framework with wide channels and responsive turn-on fluorescence for the chemical sensing of volatile organic compounds. J Am Chem Soc. 2014;136:7241-4.

21. Lü Y, Zhan W, He Y, Wang Y, Kong X, Kuang Q, Xie Z, Zheng L. MOF-templated synthesis of porous $\mathrm{CO}_{3} \mathrm{O}_{4}$ concave nanocubes with high specific surface area and their gas sensing properties. ACS Appl Mater Interfaces. 2014;6:4186-95.

22. Ai L, Li L, Zhang C, Fu J, Jiang J. MIL-53 (Fe): a metal-organic framework with intrinsic peroxidase-like catalytic activity for colorimetric biosensing. Chem A Eur J. 2013;19:15105-8.

23. Huang Y, Zhao M, Han S, Lai Z, Yang J, Tan C, Ma Q, Lu Q, Chen J, Zhang $X$. Growth of Au nanoparticles on 2D metalloporphyrinic metal-organic framework nanosheets used as biomimetic catalysts for cascade reactions. Adv Mater. 2017;29(32):1700102. https://doi.org/10.1002/ adma.201700102.

24. Zou HL, Li BL, Luo HQ, Li NB. A novel electrochemical biosensor based on hemin functionalized graphene oxide sheets for simultaneous determination of ascorbic acid, dopamine and uric acid. Sens Actuators B Chem. 2015;207:535-41.

25. He J, Yang H, Zhang Y, Yu J, Miao L, Song Y, Wang L. Smart nanocomposites of Cu-hemin metal-organic frameworks for electrochemical glucose biosensing. Sci Rep. 2016;6:36637.

26. Liu F, He J, Zeng M, Hao J, Guo Q, Song Y, Wang L. Cu-hemin metalorganic frameworks with peroxidase-like activity as peroxidase mimics for colorimetric sensing of glucose. J Nanopart Res. 2016;18:106.

27. Cui F, Deng Q, Sun L. Prussian blue modified metal-organic framework MIL-101 (Fe) with intrinsic peroxidase-like catalytic activity as a colorimetric biosensing platform. RSC Adv. 2015;5:98215-21.

28. Hamd-Ghadareh S, Salimi A, Fathi F, Bahrami S. An amplified comparative fluorescence resonance energy transfer immunosensing of CA125 tumor marker and ovarian cancer cells using green and economic carbon dots for bio-applications in labeling, imaging and sensing. Biosens Bioelectron. 2017;96:308-16.

29. Yokchom R, Laiwejpithaya S, Maneeprakorn W, Tapaneeyakorn S, Rabablert J, Dharakul T. Based immunosensor with signal amplification by enzyme-labeled anti-p16INK4a multifunctionalized gold nanoparticles for cervical cancer screening. Nanomed Nanotechnol Biol Med. 2018;14:1051-8.

30. Li Y, Wang X, Zhou Q, Zhang Y, Zhan L. A simple aptamer-functionalized gold nanorods based biosensor for early diagnosis of breast cancer in needle biopsy. Nanomed Nanotechnol Biol Med. 2016;12:477.

31. Schiffman M, Solomon D. Cervical-cancer screening with human papillomavirus and cytologic cotesting. N Engl J Med. 2013;369:2324-31.

32. Hussain T, Nguyen QT. Molecular imaging for cancer diagnosis and surgery. Adv Drug Deliv Rev. 2014;66:90-100.

33. Rand D, Walsh EG, Derdak Z, Wands JR, Rose-Petruck C. A highly sensitive $X$-ray imaging modality for hepatocellular carcinoma detection in vitro. Phys Med Biol. 2015;60:769. 
34. Zhang X, Xiao K, Cheng L, Chen H, Liu B, Zhang S, Kong J. Visual and highly sensitive detection of cancer cells by a colorimetric aptasensor based on cell-triggered cyclic enzymatic signal amplification. Anal Chem. 2014;86:5567-72.

35. Wang K, Fan D, Liu Y, Wang E. Highly sensitive and specific colorimetric detection of cancer cells via dual-aptamer target binding strategy. Biosens Bioelectron. 2015;73:1-6.

36. Qin F-X, Jia S-Y, Wang F-F, Wu S-H, Song J, Liu Y. Hemin@ metal-organic framework with peroxidase-like activity and its application to glucose detection. Catal Sci Technol. 2013;3:2761-8.

37. Maji SK, Mandal AK, Nguyen KT, Borah P, Zhao Y. Cancer cell detection and therapeutics using peroxidase-active nanohybrid of gold nanoparticleloaded mesoporous silica-coated graphene. ACS Appl Mater Interfaces. 2015;7:9807-16

38. Kwon U, Kim B-G, Nguyen DC, Park J-H, Ha NY, Kim S-J, Ko SH, Lee S, Lee $\mathrm{D}$, Park HJ. Solution-processible crystalline $\mathrm{NiO}$ nanoparticles for highperformance planar perovskite photovoltaic cells. Sci Rep. 2016;6:30759.

39. Gu C-J, Kong F-Y, Chen Z-D, Fan D-H, Fang H-L, Wang W. Reduced graphene oxide-hemin-Au nanohybrids: facile one-pot synthesis and enhanced electrocatalytic activity towards the reduction of hydrogen peroxide. Biosens Bioelectron. 2016;78:300-7.

40. Zou G, Jia X, Huang Z, Li S, Liao H, Hou H, Huang L, Ji X. Cube-shaped porous carbon derived from MOF-5 as advanced material for sodium-ion batteries. Electrochim Acta. 2016;196:413-21.

41. Deng X, Fang Y, Lin S, Cheng Q, Liu Q, Zhang X. Porphyrin-based porous organic frameworks as a biomimetic catalyst for highly efficient colorimetric immunoassay. ACS Appl Mater Interfaces. 2017;9:3514-23.

42. Zhang X-Q, Gong S-W, Zhang Y, Yang T, Wang C-Y, Gu N. Prussian blue modified iron oxide magnetic nanoparticles and their high peroxidaselike activity. J Mater Chem. 2010;20:5110-6.
43. Tao Y, Lin Y, Huang Z, Ren J, Qu X. Incorporating graphene oxide and gold nanoclusters: a synergistic catalyst with surprisingly high peroxidase-like activity over a broad $\mathrm{pH}$ range and its application for cancer cell detection. Adv Mater. 2013;25:2594-9.

44. Cui L, Wu J, Li J, Ju H. Electrochemical sensor for lead cation sensitized with a DNA functionalized porphyrinic metal-organic framework. Anal Chem. 2015;87:10635-41.

45. Zhang L-N, Deng H-H, Lin F-L, Xu X-W, Weng S-H, Liu A-L, Lin X-H, Xia $\mathrm{X}-\mathrm{H}$, Chen $\mathrm{W}$. In situ growth of porous platinum nanoparticles on graphene oxide for colorimetric detection of cancer cells. Anal Chem. 2014;86:2711-8.

46. Song Y, Chen Y, Feng L, Ren J, Qu X. Selective and quantitative cancer cell detection using target-directed functionalized graphene and its synergetic peroxidase-like activity. Chem Commun. 2011;47:4436-8.

47. Liu H, Xu S, He Z, Deng A, Zhu J-J. Supersandwich cytosensor for selective and ultrasensitive detection of cancer cells using aptamer-DNA concatamer-quantum dots probes. Anal Chem. 2013;85:3385-92.

48. Wang G-L, Xu X-F, Qiu L, Dong Y-M, Li Z-J, Zhang C. Dual responsive enzyme mimicking activity of $\mathrm{AgX}(X=\mathrm{Cl}, \mathrm{Br}$, I) nanoparticles and its application for cancer cell detection. ACS Appl Mater Interfaces. 2014;6:6434-42.

49. Hu A-L, Liu Y-H, Deng H-H, Hong G-L, Liu A-L, Lin X-H, Xia X-H, Chen W. Fluorescent hydrogen peroxide sensor based on cupric oxide nanoparticles and its application for glucose and I-lactate detection. Biosens Bioelectron. 2014;61:374-8.

50. Yin $\mathrm{H}$, Too $\mathrm{H}$, Chow $\mathrm{G}$. The effects of particle size and surface coating on the cytotoxicity of nickel ferrite. Biomaterials. 2005;26:5818-26.
Ready to submit your research? Choose BMC and benefit from:

- fast, convenient online submission

- thorough peer review by experienced researchers in your field

- rapid publication on acceptance

- support for research data, including large and complex data types

- gold Open Access which fosters wider collaboration and increased citations

- maximum visibility for your research: over 100M website views per year

At BMC, research is always in progress.

Learn more biomedcentral.com/submissions 